\title{
THE HALAL ASPECT AND ISLAMIC FINANCING AMONG MICRO, SMALL, AND MEDIUM ENTERPISES (MSMES) IN YOGYAKARTA: DOES BERKAH MATTER?
}

\author{
Abdul Qoyum ${ }^{1}$ and Neneng Ela Fauziyyah ${ }^{2}$ \\ ${ }^{1}$ UIN Sunan Kalijaga Yogyakarta, Indonesia, qoyum13@gmail.com \\ ${ }^{2}$ International Islamic University Malaysia (IIUM), Malaysia, nenengelafauziyyah@gmail.com
}

\begin{abstract}
The development of Halal industry points out an amazing result around the world, including Indonesia. Surprisingly, the biggest contributor for its growth is Micro, Small and Medium Enterprises (MSMEs). In order to improve its significant contribution, the combination of Halal MSMEs and Islamic financing becomes very crucial. Nevertheless, there is still a lack of awareness of the concept and of intention from MSMEs regarding the penetration of Islamic financing. Therefore, this study investigates the determinants affecting the MSMEs' desire for utilizing Islamic financing from the Islamic financial institution and encouraging Halal MSMEs to adopt Islamic financing in all business activities. A survey was conducted on 58 MSMEs in Yogyakarta, Indonesia by employing self-administered questionnaire as the main approach for data collection. By using Structural Equation Modeling- Partial Least Square (SEM-PLS) analysis, this study reveals that from the variables examined, Cost Benefit and Halal Awareness are the two factors that have impact on the Use of Islamic Financing. In addition, Cost Benefit and Reputation are the two variables that have direct impact on the Attitude of MSMEs toward Islamic Financing. Interestingly, this research also finds that Berkah as the key component in Islamic financing will be gained by MSMEs when they use Islamic financing instrument, and, thus will encourage Halal MSMEs' intention to reuse Islamic financing. Moreover, service quality and competitiveness are very crucial to maintain the customer satisfaction. In addition, preaching Berkah as key component in Muslim life is an important agenda in the future development of Halal Industry, especially in MSMEs sectors.
\end{abstract}

Keywords: Halal Industry, MSMEs, Islamic financing, Attitude, Re-using Islamic financing. JEL Classification: H8; L11; L60.

\author{
Article history: \\ Received : November 30, 2018 \\ Revised : March 01, 2019 \\ Accepted : March 04, 2019 \\ Available online : March 15, 2019
}

https://doi.org/10.21098/jimf.v5i1.1055 


\section{INTRODUCTION}

Halal industry can be seen as the key sector for the future development of Muslim globally. The size of Halal industry globally is estimated about $\$ 3$ trillion in 2021, with the contribution of halal food amounting to $\$ 1,914$ billion, halal travel $\$ 243$ billion, modest fashion $\$ 368$ billion, halal media and recreation $\$ 262$ billion, halal pharmaceutical $\$ 132$ billion, and halal cosmetics $\$ 81$ billion. Islamic financing and Islamic banks are predicted to reach around 5 trillion in 2021 (Thomson Reuters, 2017). It means that if both markets are combined, the size is around $\$ 8$ trillion. In terms of ranking, Indonesia, as the most populous Muslim countries in the world, with more than 245 million people as potential market, in fact stand in the top 10 ranks for overall halal sector. Therefore, to improve Indonesia's ranking as a main market player in halal industries, all of stakeholder in Indonesia must work stronger, for currently halal industry can contribute significantly to economics growth (Jaffar and Musa, 2016). One of the most important strategies in improving halal industry is by combining halal sector and Islamic financing.

In Indonesia, there remains some disconnection between Islamic financing and halal industry, especially for Small and Medium Enterprises (MSMEs) (Yunos et al. 2014). The lack of awareness from the player of halal industry affects the low penetration of Islamic financing and banking in Indonesia. Thus, the stagnant market share of Islamic bank at $5 \%$ is a reasonable fact. This phenomenon not only occurs in Indonesia, but also in Malaysia. According to Badlyshah (2011), there were only $95 \%$ of halal players using Islamic banking and financing as their financing instrument, while the rest were users of Islamic financing (Jaffar and Musa, 2016). In contrast, according to sharia parameters, halal is considered not only from the production perspective, but also all aspects of their operation including for financing their business (Jaffar and Musa, 2014). Hence, in this perspective, the merging or integrating Islamic financing into Halal industry in Indonesia is a critical issue.

MSMEs in Yogyakarta play a vital role in the development of economy. With the nature of the province as the tourism destination and city of education, Yogyakarta attracts many visitors to stay and visit. Hence, it is not surprising that there are many MSMEs in Yogyakarta, especially in food and fashion sectors. In Yogyakarta, there are around 2082 MSMEs, distributed in 7 sub-districts (Kecamatan). ${ }^{1}$ Integrating the current practice of Halal industry with Islamic financing will create mutual benefits. Islamic financing, according to Kassim (2016), has an important contribution to the real economy by channeling funds into the investment activities. With the nature of MSMEs as a less profitable firm, Islamic financing benefits this industry (Minhat and Dzolkarnaini, 2017). If the collaboration between Islamic financing and MSMEs in Yogyakarta in this context can be made in such a way, it will lead to a development of MSMEs that in the end will promote economic growth for the country, providing more than $90 \%$ of employment (Huda, 2012).

To the best of the authors' knowledge there are limited empirical studies on the relationship between Halal industry and Islamic financing. Jaffar and Musa (2016) conducted empirical study on the determinants of Halal MSMEs in using

1 http://umkm.jogjakota.go.id/direktori2/group.php, retrieved in September 26, 2018. 
Islamic financing in their business activities. By testing 205 halal MSMEs, this study indicated that religion obligation was the strongest impact on attitude. However, such findings contradicted the study by Balushi, Locke, and Boulanouar (2018) that suggested religiosity had significant negative impact on the intention of MSMEs to use Islamic financing.

In addition, the study of Jaffar and Musa (2016)) also showed that perceived behavioral control and subject norm were the two factors affecting the MSMEs attitude to use Islamic financing products. This study had some limitations, in that it did not measure the halal awareness of MSMEs and Berkah that had impact on the use of Islamic financing. As we know, the concept of business in Islam is restricted on how to acquire and utilize the assets (halal and haram aspects) including in financing. In fact, this is the way to reach business orientation in Islam. As mentioned by Norvadewi (2015) profit (material) and benefit (non-material), development, sustainability, and Berkah (the blessing from Allah) are the key goals of having business in Islam. Especially on Berkah, every Muslim believes that Berkah belongs to and is the right of God for whomever He wants to give. Once a Muslim receives berkah in an aspect of his or her life, he/she will feel abundant of it even though it is not much substantially. This is because of the unseen gift from the God (Demiler \& Sahib, 2015). Thus, Berkah aspect becomes an important element that must be achieved by Muslims, including Muslim entrepreneurs.

Based on this framework, this study attempts to investigate the determinants that influence the attitude of MSMEs toward Islamic financing. In addition, this study also discusses the determinants of using Islamic financing by combining attitude aspect, halal knowledge, and cost benefit. The new insight in this paper is the introduction of the impact of using Islamic financing on the Berkah that is gained by the customers. Lastly, this study covers the testing of the determinant of customers for re-using Islamic financing product. The remainder of this paper is organized as follows: section two discusses literature review; section three discusses on conceptual framework and development of hypothesis; section four elaborates on research methodology; section five discusses the empirical findings and discussion; and section six is conclusion and recommendation.

\section{LITERATURE REVIEW}

The following concepts are the groundwork of this current research since the authors want to know the intention and interest of MSMEs to use Islamic financing and how far they consider Berkah aspects in all their business activities.

\subsection{The Definition, Types and Sharia Views of Islamic Financing}

According to Jaffar and Musa (2014), Islamic financing is defined as a financial service system covered by a product that should comply with the sharia principles and Islamic law. This compliance is established by its relationship with aqad consisting of five concepts: (1) pure deposit principles (Wadi'ah), (2) selling and buying principles (Tijarah), (3) profit-sharing principles (Syirkah), (4) leasing principles (Ijarah), and (5) service or fee principles (Ajr walumullah) (Wulandari and Subagio, 2015). Islamic financing should also be aware of the distinctive 
identity of Islam, such as riba (interest), maysir (gambling), gharar (speculative), as well as haram (forbidden), and halal (permissible) (Jaffar and Musa, 2014). These principles have become the distinguishing factors between Islamic financing and its counterpart, the conventional financing.

In terms of a particular concept of financing, the ideal means of financing in Islamic financing is profit-and-loss sharing. Apart from an alternative of riba, this approach also may decrease wealth and income inequality distribution (Rahman, 2010), create economic growth with long-term period, as well as enhance capital distribution efficiency in which depends on the productivity (Kassim, 2016). The most essential aspect is that profit-and-loss sharing is not only meets the maqasid shariah (objectives of sharia), but also fulfills the objectives of Islam (Fianto et al., 2017).

Islamic financing can be divided into two: Sharia-compliant and Shariabased. Sharia-based financing signifies the return obtained is not fixed and cannot be determined before the contract started. The contracts used in Shariabased financing consist of musyarakah (equity partnership) and mudlarabah (profit-sharing). Meanwhile, Sharia-compliant financing means that the return is predetermined between the parties before the project started;. The contracts used include murabahah (cost plus profit sale), Ijarah (lease arrangement), Bai Salam (spot payment for future delivery), diminishing musyarakah (housing financing), Bai Muajjal (sale on deferred payment) and Istishna (order to manufacture) (Hanif and Iqbal, 2010).

\subsection{Micro, Small and Medium Enterprises (MSMEs)}

Micro, Small and Medium Enterprises (MSMEs) are independent firms that hire a few numbers of employees and are generally non-subsidiary. The given numbers of employees are varied across countries (OECD). ${ }^{2}$ In Indonesia, the definition of MSMEs is different based on asset and turnover. According to the Ministry of Cooperatives and MSMEs under Act No. 20 of 2008, the maximum asset and turnover for micro enterprises are IDR 50 million and IDR300 million, for small enterprises should not exceed IDR500 million and IDR2.5 billion respectively. Meanwhile, medium enterprises have to have the range asset between IDR500 million and IDR10 billion, while the turnover should not exceed IDR50 billion. In addition, Central Bureau of Statistics divides MSMEs based on the number of employees. Household enterprises normally employ 1-5 employees, while small and medium enterprises 6 to 19 employees, medium enterprises 20 to 29 employees, and large enterprises more than 100 employees respectively (Merina, 2016). ${ }^{3}$

The regulation governing MSMEs in Indonesia is Act No. 20/2008 (also known as the MSMEs Act) under the Ministry of Co-operatives and MSMEs. The MSMEs have the most important roles. Besides increasing economic growth from GDP as well as export-import, MSMEs also create jobs and suppress unemployment.

\footnotetext{
2 https://stats.oecd.org/glossary/detail.asp?ID=3123. Retrieved in October 9, 2018.

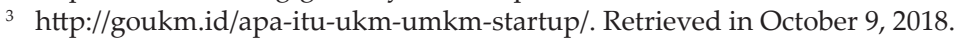


In Yogyakarta, MSMEs are categorized by three types: micro, small, and medium enterprises. There are 2082 MSMEs comprising 1822 micro enterprises, 237 small enterprises; and 23 medium enterprises, which engage in various sectors, including handicraft, food, fashion, metal and electronic, materials, and many others. Handicraft and food sectors still dominated the market in 2018 (UMKM Kota Yogyakarta). ${ }^{4}$

\subsection{The Concept of Halal and Berkah}

The definition of halal is the permissibility all aspects and activities due to a compliance with Islamic law or sharia (Bahruddin, Kassim, Nordin, \& Buyong, 2015). If the aspects and activities violate the sharia law, they will be disallowed and known as haram or non-halal because impermissible products consist of gharar, maysir, and riba. In a business point of view, ensuring halal aspects in all business activities may lead entrepreneurs to reach the main goal of human prosperity, which is Berkah.

The word berkah or barakah is originated from three latter ba-ra-ka which means growth, happiness, appreciation, and excess as mentioned by Demiler \& Sahib (2015). Berkah is known as the blessing from the God as Mubarak (the blessed). Muslims understand that Berkah only given from the God as His appreciation for the servant's obedience. Berkah can be in many forms and ways such as family, wealth, health, knowledge, and businesses as well. Qur'an mentions Berkah repeatedly in many surahs. It is a gift for the people, their places, times, and chances, as well as objects such as water, dates, olive, etc.

\subsection{Previous Studies}

From the customer's perspective, both conventional financing and Islamic financing have their own attractions. The customers can decide which kind of financing they will. Nevertheless, when customers particularly prefer halal industry, they expect the financing type to make sure all their activities comply with sharia principles. Thus, the emerging of Islamic financing could become a solution for their challenges. As Dasuki (2008) suggests that Islamic financing, particularly Islamic banks, has to have the purpose of promoting Islamic norms and values in order to reach the sharia objectives, rather than focusing on only escalating their profit. By doing so, Islamic banks are able to demonstrate their reputation. One of the ways is by creating sharia-compliant products. However, in the case of the distinct lending approaches between conventional and Islamic banks, it appears as difficulties faced by the costumer as well as the institution. Shaban, Duygun, and Fry (2016) found that the impact of their distinctive was bank cost that will increase the price and market competition. The author used the two-stage competition model of Bertrand framework (competition of price) as the first stage and Cournot framework (loan output) as the second stage. In Islamic banks, even though price competition will encourage attaining market share

4 http://umkm.jogjakota.go.id/direktori2/group.php?mod=klas Retrieved in October 9, 2018. 
because of their differentiated product in the first stage, but market competition could cause the lending output amount of MSMEs to go down.

While 98.79\% MSMEs are under the microenterprise category (Ascarya \& Rahmawati, 2018), they are expected to get in touch with Islamic financing. Before the 1998 financial crisis, Boocock and Preseley (1993) conducted a study on MSMEs and Islamic financing or venture capital. They found that at that time Islamic financing and venture capital were slow to grow due to the lack of equity-linked funding, as opposed in Malaysia where MSMEs did not have the knowledge to apply for funding. Even when an application was submitted, Islamic financing could not get much information from the enterprise because of the conventional management. After the crisis, most people knew that Islamic financing could survive during a crisis, and the continual growth of Islamic financing could be materialized.

On the other hand, Rahman (2010) discovered that Islamic financing may provide various schemes under the ethical principles. The instruments consist of qardhul hasan, murabahah, and ijarah, as well as participatory instruments, such as mudharabah and musyarakah. Such instruments proved to have great potentials to assist micro-entrepreneurs and people in need. Fianto et al. (2017) conducted a study on rural household in Indonesia using a survey questionnaire administered with 548 respondents. There are two groups of financing consisting of equity and debt-based financing. They found that both financing groups showed a positive impact on the income of rural household, even though debt-based financing was not much better than equity performance. This result confirmed Huda (2012) in that his findings concluded that due to asymmetric information, Islamic banks preferred to use debt-based instruments rather than the profit-sharing scheme, which are equity-based. This preference was strengthened by MSMEs as a customer, as MSMEs will not consider a higher charge as long as they could get lending with a fast procedure. Therefore, the combination efforts from the government and Islamic banks are essential. The government can assist Islamic banks in identifying potential MSMEs. Additionally, the government should also cooperate with the academia to create the valuation system of MSMEs credit scoring. However, Hussaini and Malami (2014) studied the desire of Small Scale Business (SSB) in Kano, Nigeria to access funds through the profit and lost sharing (PLS) scheme due to the hard effort of SSB to get funding from conventional banks. The study revealed that there were $70 \%$ respondents getting ready to know more about PLS. In addition, up to $80 \%$ respondents were aware of the Profit-and-Loss Sharing (PLS) principles. Thus, we could conclude that many SSBs prefer to use the profit and lost sharing scheme for their enterprises.

In addition, Amin, Rahman, Jr, and Hwa (2011) emphasized the indicators encouraging the use of Islamic financing by surveying 150 customers of two fully-fledged Islamic banks, Bank Islam Malaysia Berhad and Bank Muamalat Malaysia Berhad, in order to assess the intention for using Islamic financing. They found three factors most influencing customer's choices: attitude, social influence, and pricing of Islamic personal financing. Religiosity as well as the government support provided the insignificant indicators. A negative effect of religious obligation toward Islamic banking products was also supported by Bodibe, Chiliya, \& Tarisayi (2016), even though attitude was in contrast with that. In this 
study, the attitude of utilizing Islamic banking product was positively affected by both community influence and social norms.

As for the enterprise, Gait and Worthington (2009) investigated business firm attitudes out of 296 firms surveyed toward the Islamic financing method. They found that the majority of business firms in Libya preferred utilizing Islamic banking and financing due to their previous knowledge although they were using informal financing. The encouragement by enterprises to use Islamic financing was caused by four factors such as religion, business support, profitability, and unique services, with religion being the main determinant. On the other hand, a study conducted by Zainuddin, Hamja, \& Rustiana (2016) employed a process of applying Islamic financing in Sharia Mandiri Bank of Indonesia as the dominant factors to encourage MSMEs to use the financing type.

Rustam, Bibi, Zaman, Rustam, \& Zahid-ul-Haq (2011) also examined the perception of corporate customers toward Islamic commercial banking products and services in Pakistan. They conducted the survey on corporate customers of six banks. The result suggested that even though the customers had less knowledge of Islamic bank, Islamic bank still had a great potential in Pakistan. The main factors encouraging it were religion and the economy, particularly costs and benefits obtained by the company. The other factors, such as service delivery, bank size and reputation, convenience as well as friendliness of bank employees, were still behind. Rasheed, Siddiqui, \& Rahman (2018) conducted a study in Pakistan on the awareness of SMEs to utilize Islamic financing in their business. Although it was still a pilot project, the study revealed that five factors used, i.e., intention, attitude, awareness, subjective norms, and perceived behavioral control were reliable and achieved internal consistency to be continued in the next stages of their study. Moreover, in Jordan, Nawafleh, Al-Ajlouni, Al-Tamimi, \& Shiab (2018) also set up similar research. By using Structural Equation Modeling (SEM), they found religious identity, social factors, and attitude as the main determinants for customers to practice Islamic financing.

However, above all, there is no study highlighting halal awareness and Berkah as one of the factors encouraging the use of Islamic financing. Most of the previous researchers only discussed the religion aspect, attitude, as well as business factors. Based on this research gap, this study attempts to make comprehensive analysis on the determinants factors affecting the use of Islamic financing among MSMEs.

\section{CONCEPTUAL FRAMEWORKS AND DEVELOPMENT OF HYPOTHESES 3.1. The Concept of Intention in Islam}

Generally speaking, intention is the basic learning in Islam. The Qur'an cites intention in several verses. One of them is al-Isa' verses 19 by revealing intention with word 'al-iradah' (desire). It states that:

"But whoever desires the Hereafter and exerts the effort due to it while he is a believerit is those whose effort is ever appreciated (by Allah)."

Based on Arbain An-Nawawi and Shahih Bukhari, the traditional literature, hadist on intention comes up in the first position, signifying that intention is one of the essential aspects in every human' attitude. Cited from Sakti, Thaker, Qayum, \& Qizam (2016), in hadist, the Prophet Muhammad declares: 
"The reward of deeds depends on the intentions and every human will get reward according to what he has intended. Whoever emigrated for Allah and his Prophet, his emigration will be for Allah and his Prophet; whoever emigrated for seeking worldly benefit or for a woman to marry, his immigration would be for what he emigrated for."

Terminologically speaking, intention is al-qashdu (desire) or al-iradah (desire) or al-ibtigo' (purpose, aimed). Then, intention is defined as carrying the deeds out for something else. Thus, everyone who has intention will get as he intends to. Good intention will deliver benefit, while bad intention bad result.

As for the intention with utilizing Islamic financing, this study surveys the factors affecting MSMEs enterprises' desire for applying for funding to the Islamic financing and encouraging MSMEs enterprises to adopt Islamic financing on all business activities. We determine ten main variables: Attitude, Cost Benefit, Knowledge, Religion, Business Support, Reputation, The Use of Islamic Financing Product (Using), Halal Awareness, Berkah, and Intention.

\subsection{Cost Benefit and Attitude}

Cost benefit signifies the value undertaken from the cost used and profit attained. Normally, every company may consider it before they decide to execute their financial activities: how much will it take to produce and how much to gain (Jaffar and Musa, 2016). On the other hand, a study conducted by Huda (2012) provides a contrastive analysis. He reported that MSMEs costumers interviewed did not take care of financing cost charged by Islamic banks. In fact, they only desired to get financing with fast processes as well as simple products and services. That said, the hypothesis of this study is described as follows:

$H_{0} \quad$ : Cost Benefit does not significantly influence the attitude

$H_{1} \quad$ : Cost Benefit significantly influences the attitude

\subsection{Knowledge and Attitude}

Knowledge has an important role in determining choices. People who have full knowledge may make better choices because they could predict the benefits they will get. As for knowledge of Islamic financing, Ahmad and Haron (2002) claimed that the lack of knowledge caused more than 65 per cent respondents admitting that if Islamic banks wanted to survive in the market, they should maximize their profit as high as the conventional banks. Islamic banks should also decrease their costs to attract more customers. Thus, customers had to have proper knowledge of Islamic financing in order to avoid misperception on it. Based on its view, the following hypothesis describes the assumptions:

$H_{0} \quad$ : Knowledge does not significantly influence the attitude

$H_{1} \quad$ : Knowledge significantly influences the attitude

\subsection{Religion and Attitude}

Because Islamic financing is known as the financial facilities under Islamic principles, Islam as a religion may provide a wide influence to customer's perception. Obedient people of religion could be guaranteed that they will perform 
well upon their trust as the command of Allah mentioned in Adh-Dhariyat verse 56:

"And I did not create the jinn and mankind except to worship Me."

The previous studies proved that religion becomes the fundamental factor in detecting customers' attitude in and choices of Islamic banking (Gait et al., 2009). Moreover, Jaffar and Musa (2014) examined the attitude of respondents with regard to religion obligation. The customers interviewed recognized the obligation of using all services complying with sharia that pressed them to apply financing in the Islamic financial institution.

Thus, based on the literature the hypothesis is as follows:

$H_{0} \quad$ : Religion does not significantly influence the attitude

$H_{1} \quad$ : Religion significantly influences the attitude

\subsection{Business support and Attitude}

Business support signifies any element that Islamic financing can support and encourage the companies' business. If customers can proof that, they will believe that Islamic financing has the equitability to being both financial and non-financial supporting partners. Gait et al. (2009) mentioned that one of the factors determining business companies' attitude is business support. Based on that, the hypothesis is built as follows:

$H_{0} \quad$ : Business support does not significantly influence the attitude

$H_{1} \quad$ : Business support significantly influences the attitude

\subsection{Reputation and Attitude}

As far as reputation is concerned, the conclusion of study from Kasuma, Su, Kanyan, Kamri, \& Yacob (2016) stated that specific companies, such as hotels, hospitals, and banks, required customer loyalty in order to survive their business. Customer loyalty can be attracted by providing best service and relationship quality as well as reputation. The Islamic bank reputation may increase market shares due to the trust from the customer, and it will form their loyalty to always use Islamic banks. Based on its view, the hypothesis would be as follows:

$H_{0} \quad$ : Reputation does not significantly influence the attitude

$H_{1} \quad$ : Reputation significantly influences the attitude

\subsection{Attitude and The Use of Islamic Financing Products (Using)}

Even though the majority of studies on halal product is in non-financial areas, such as food, cosmetics, and pharmaceutical product, the study from Mukhtar, Butt, Mukhtar, \& Butt (2012) on the intention to choose Halal non-financial products is still relevant to the financial perspective. This is due to Islamic financing being one of Halal products that are also developed. They found that customer attitude, subjective norms, and intra- and inter-personal religiosity have positive impact to the intention of choosing Halal products in Pakistan. Therefore, the hypothesis would be as follows: 
$H_{0} \quad$ : Attitude does not significantly influence the use of Islamic financing product

$H_{1} \quad$ : Attitude significantly influences the use of Islamic financing product

\subsection{Cost Benefit and the Use of Islamic Financing Product (Using)}

Existing studies have examined that besides religion, economic determinants have a great deal of impact to the customer's decision in utilizing Islamic banking. Such determinants are cost and benefit gained by the company, service delivery, size and reputation of the Islamic banks, convenience, and friendliness of bank employees (Rustam et al., 2011). Another study found that cost benefit became one of determinants establishing Islamic financing used by MSMEs customers (Jaffar and Musa, 2014). Therefore, the hypothesis is built as follows:

$H_{0} \quad$ :Cost Benefit does not significantly influence the use of Islamic Financing Products

$H_{1} \quad$ : Cost Benefit significantly influences the use of Islamic financing product

\subsection{Halal Awareness and the Use of Islamic Financing Product (Using) (IF)}

Logically, when people are aware of a concept or idea, they are encouraged to do something about it. In the case of awareness on Halal products, people who aware on it will be encouraged to use the products. In this case, Ling, Ling, Pey, and Hui (2012) conducted research that examined awareness, understanding, and perception of non-Muslim customers in Islamic banking in Malaysia. They stated that most of the respondents were aware of Islamic banking, but they did not know the details of the products and services offered. Based on such notion, the hypothesis is built as follows:

$H_{0} \quad$ : Halal awareness does not significantly influence the use of Islamic Financing products

$H_{1} \quad$ : Halal awareness significantly influences the use of Islamic Financing products

\subsection{The Use of Islamic Financing Product (Using) and Berkah}

The objective of consumers in Islam is to attain Maslahah that consists of Manfaat (utility) and Berkah. Conceptually, manfaat will be gained by every customer when they consume any product whether or not it is halal. However, in case of berkah, it will be generated by consumers when they use Islamic or shariah compliance product. ${ }^{5}$ Therefore, in this case, MSMEs that use Islamic financing will get Berkah in their lives in terms of the significant growth of their businesses and of happiness in their activities. Therefore, the hypothesis is as follows:

$H_{0} \quad$ : The use of Islamic financing products does not significantly influence the Berkah

$H_{1} \quad$ : The use of Islamic financing products significantly influences the Berkah

5 See, in Ekonomi Islam, written by BPFE UII in collaboration with Bank Indonesia, chapter 4, page135142. 


\subsection{Berkah and Intention}

Berkah as the key element in Islamic financing has a direct impact on the customer loyalty in using shariah-compliant products. When the customer gains Berkah, the intention of customer to re-use Islamic financing will increase. Therefore, the total Maslahah will also jumped drastically (P3EI and BI, 2012). Based on it, the hypothesis is built as follows:

$H_{0} \quad:$ Berkah does not significantly influence the Intention to re-use Islamic financing $H_{1} \quad$ : Berkah significantly influences to the intention re-use Islamic financing

\subsection{The Use of Islamic Financing Products (Using) and Intention}

Many efforts have been initiated by Islamic banks to accomplish customer satisfaction, such as human resources, core product, service delivery, service capability, and social responsibility (Ardhy, 2015) because satisfaction is the key factor in order to predict customers on what they will cooperate again with Islamic banks. Lone, Aldawood, \& Bhat (2017) in their comparative study found that customers were satisfied with both conventional and Islamic banks in Saudi Arabia. This result showed the ability of Islamic banks to compete in the market. In case of non-Muslim customers, Farid (2013) proved that non-Muslim were also satisfied with Islamic bank services. Therefore, this study forms the hypothesis as follows:

$H_{0} \quad$ : The use of Islamic financing product does not significantly influence the intention to re-use Islamic financing

$H_{1} \quad$ : The Use of Islamic financing product significantly influences the intention to re-use Islamic financing

\subsection{Halal Awareness and Intention}

In the case of Australia, Rammal \& Zurbruegg (2007) found that the awareness of Australian Muslim on Islamic banking motivated their interest to use Islamic banking's products, although only in credit products. Basically, the higher the awareness of the customer on Islamic financing instrument, the more fervent for them to re-use this product. Consequently, the intention to loyal in Islamic financing will increase. Therefore, the hypothesis is as follows:

$H_{0} \quad$ : Halal awareness does not significantly influence the intention of re-use Islamic financing

$H_{1} \quad$ : Halal awareness significantly influences the intention of re-use Islamic financing

\section{RESEARCH METHODS}

The case study involves MSMEs in Yogyakarta, Indonesia. Data were collected using self-administered questionnaires. The direct survey was randomly distributed for MSMEs in Yogyakarta City, totaling 70 surveys, but only 58 were returned due to time constraints and difficulties in contacting the owners of MSMEs directly. A Likert-scale based questionnaire was developed (1-Strongly Disagree and 5-Strongly Agree) to measure the information from MSMEs. The language used in this questionnaire was Indonesian. 50 items set out in different indicators and were developed based on literature and existing studies. 
In terms of analysis purposes, Structural Equation Modeling-Partial Least Square (SEM-PLS), SmartPLS 3.0 has been used for measuring the hypothesized relationship among construct variables, validating the research model, and deciding the key determinants of attitude, and assessing the intention to re-use Islamic financing. As a result, the SEM-PLS technique provides several advantages because it does not require any complicated assumptions, such as sample size and distribution (Ghazali, 2015; F. Hair Jr, Sarstedt, Hopkins, \& G. Kuppelwieser, 2014). Therefore, with a relatively small sample of 58 , this study employs SEM-PLS. Furthermore, the technique is also used for complicated cause-effect relationship models as in this study, which includes several latent constructs that are indirectly measured by several indicators (Richter, Sinkovics, Ringle, \& Schlägel, 2016).

\section{FINDINGS AND ANALYSIS}

To begin with, this study presents the descriptive statistics of the samples based on demographic and business characteristics. Table 1 reveals that all MSME owners in Yogyakarta were $100 \%$ Muslim, consisting of $59 \%$ female and $41 \%$ male. Over $67 \%$ sample of MSMEs-owners held a high-school education and its equivalent, and about $27 \%$ obtained an undergraduate degree. In addition, $47 \%$ respondents were 20-30 years of age. Such percentages appear to be consistent with a prior studies, i.e. Metawa and Almossawi (1998) that suggested the exploring of the people's perceptions and customers within the age 20-50 years group indicated more influence on the policies. Hence, this study may provide a useful picture about investigating the determinants of halal-MSMEs using Islamic financing.

Table 1.

Descriptive Statistics

\begin{tabular}{lllc}
\hline No & & PROFILE OF RESPONDENTS & Valid Percent \\
\hline \multirow{2}{*}{ Gender } & Male & 41 \\
& & Female & 59 \\
\hline \multirow{2}{*}{2} & \multirow{2}{*}{ Age } & 20-30 Years & 4 \\
& & $31-40$ Years & 25 \\
& & $41-50$ Years & 18 \\
& & $>50$ Years & 10 \\
\hline \multirow{2}{*}{3} & \multirow{2}{*}{ Merital Status } & Single & 40 \\
& & Married & 60 \\
\hline \multirow{4}{*}{4} & \multirow{2}{*}{ Education Level } & SMP/SMA/SMK/MA & 67 \\
& & S1 (Diploma) & 6 \\
& & Undergraduate & 27 \\
& & Master & 0 \\
& & Ph.D & 0 \\
\hline \multirow{2}{*}{5} & \multirow{2}{*}{ Income } & $<$ IDR200Million & 95 \\
& & IDR .200-IDR 500Million & 5 \\
& & IDR500Million-IDR 1 Billion & 0 \\
\hline
\end{tabular}


Table 1.

Descriptive Statistics (Continued)

\begin{tabular}{|c|c|c|c|}
\hline $\mathrm{No}$ & PROI & ESPONDENTS & Valid Percent \\
\hline \multirow{6}{*}{6} & \multirow{6}{*}{ Religion } & Islam & 100 \\
\hline & & Kristen & 0 \\
\hline & & Budha & 0 \\
\hline & & Hindu & 0 \\
\hline & & Konghucu & 0 \\
\hline & & Other & 0 \\
\hline \multirow{4}{*}{7} & \multirow{4}{*}{ Number of Employment } & $<5$ orang & 81 \\
\hline & & 5 - 10 persons & 12 \\
\hline & & $10-50$ persons & 7 \\
\hline & & $>50$ persons & 0 \\
\hline \multirow{5}{*}{8} & \multirow{5}{*}{ SME Sectors } & Food & 79 \\
\hline & & Fashion & 8 \\
\hline & & Services & 7 \\
\hline & & Craft & 4 \\
\hline & & Other & 2 \\
\hline
\end{tabular}

The result from descriptive statistics indicates that from the income collection, 95\% MSMEs are below IDR200 million, and the rest are ranged between IDR 200 million - IDR 500 million. Accordingly, the figures represent that all respondents are within MSMEs category. 81\% staff respondents were less than 5, about $12 \%$ between 5 and 10, and about 10-50 respectively. Moreover, Table 1 indicates the types of businesses: $79 \%$ are in Food, $8 \%$ in fashion, $7 \%$ in service, and $4 \%$ in craft.

Table 2.

The parameter of Validity and Reliability Test

\begin{tabular}{lccc}
\hline Variable & Indicator & $\begin{array}{c}\text { Validity (Loading }> \\
\mathbf{0 . 6 )}\end{array}$ & $\begin{array}{c}\text { Reliability (Composite } \\
\text { Reliability>0.6) }\end{array}$ \\
\hline \multirow{2}{*}{ Halal } & Q1 & 0.674 & 0.625 \\
\hline Using & Q2 & 0.674 & 1 \\
\hline \multirow{3}{*}{ Knowledge } & Q4 & 1 & \multirow{2}{*}{0.807} \\
& Q5 & 0.669 & \\
& Q6 & 0.764 & 0.813 \\
\multirow{2}{*}{ Religion } & Q8 & 0.756 & \multirow{2}{*}{0.865} \\
& Q9 & 0.666 & 0.806 \\
\hline \multirow{2}{*}{ Cost Benefit } & Q10 & 0.692 & \\
\hline \multirow{2}{*}{ Business Support } & Q13 & 0.873 & \\
\hline
\end{tabular}


Table 2.

The parameter of Validity and Reliability Test (Continued)

\begin{tabular}{lccc}
\hline Variable & Indicator & $\begin{array}{c}\text { Validity (Loading }> \\
\mathbf{0 . 6 )}\end{array}$ & $\begin{array}{c}\text { Reliability (Composite } \\
\text { Reliability>0.6) }\end{array}$ \\
\hline \multirow{2}{*}{ Reputation } & Q24 & 0.858 & 0.851 \\
& Q26 & 0.864 & \\
Attitude & Q28 & 0.798 & 0.851 \\
& Q29 & 0.78 & \\
& Q30 & 0.757 & \\
Intention & Q31 & 0.651 & 0.939 \\
& Q32 & 0.657 & \\
\hline \multirow{5}{*}{ Berkah } & Q35 & 0.875 & \\
& Q36 & 0.822 & 0.883 \\
& Q37 & 0.918 & \\
\hline
\end{tabular}

Table 3 describes the parameter validity and reliability in this study. The test of convergent is used to find out about the correlation among indicators used in a single construct. The convergent validity is complied if indicators used in a single construct are related. The requirement of the convergent validity must have a loading value greater than 0.6; as for exploratory research AVE (Average Variance Extracted), the number is more than 0.5. Based on the testing result, all indicators are valid, which is indicated by the loading factors that exceed 0.6 (Ghozali, 2015).

Reliability testing was used to investigate the consistency and accuracy of an indicator in measuring a construct. In the application of SEM-PLS, there are two types in measuring: Cronbach's Alpha and Composite Reliability. As for reliability testing Table 3 shows that all variables are valid in which the composite reliability exceeds the minimum cut of point $(>0.6)$. Therefore, this testing provides an evidence that all parameters fulfill all the requirements for doing SEM testing by employing Smart PLS. 


\section{Figure 1. Structural Model's}

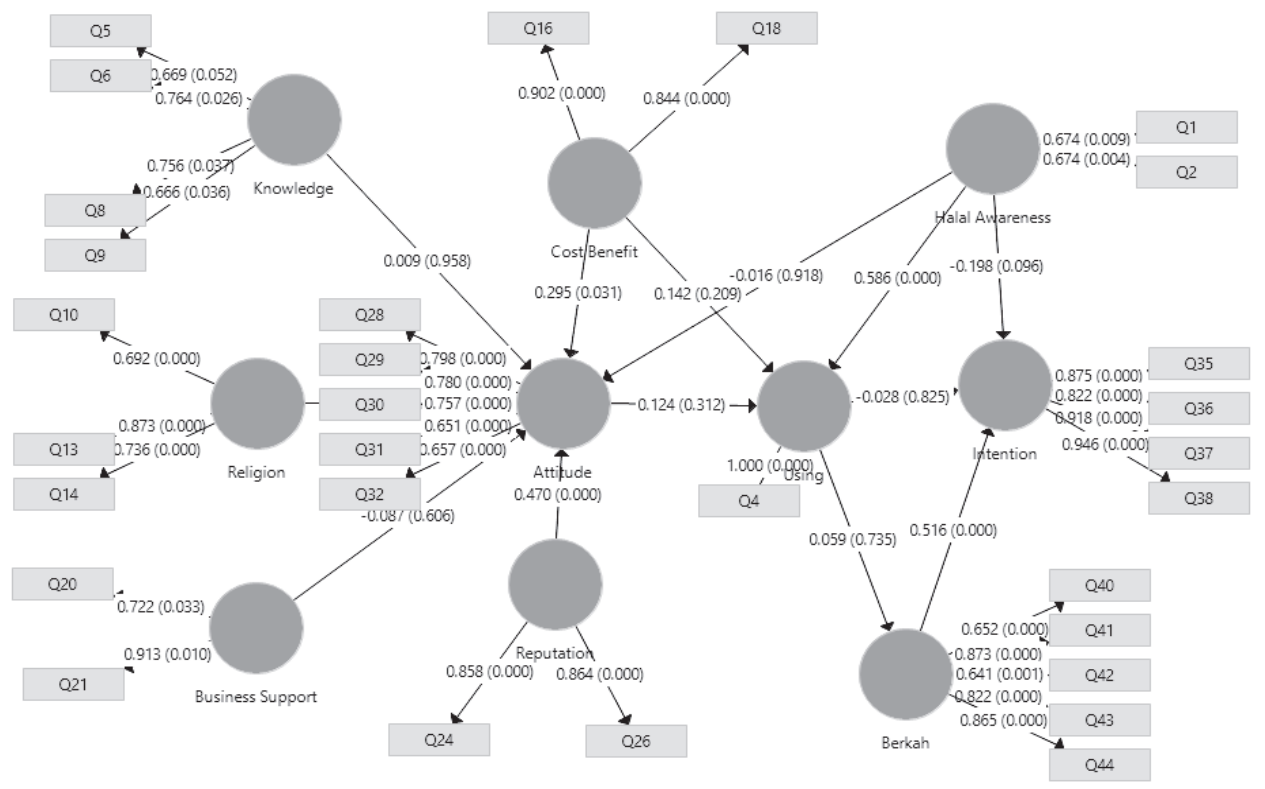

In total there are twelve main hypothesis developed in this study, with details of these hypothesis described in Table 4. As for the determinant of MSMEs attitude on Islamic financing, five hypotheses were used. Three hypotheses were developed for factors that determine the use of Islamic financing. Last, three hypotheses were used to figure out the determinants of Intention to re-use Islamic financing among MSMEs. The rest is the hypothesis pertaining to the impact of Using Islamic financing on the Berkah received by MSMEs.

Table 3.

Hypothesis Testing Result

\begin{tabular}{llcccc}
\hline Hypothesis & \multicolumn{1}{c}{ Hypothesized path } & $\begin{array}{c}\text { Std path } \\
\text { coefficient }\end{array}$ & $\begin{array}{c}\text { Critical } \\
\text { Ratio }\end{array}$ & Prob & Remark \\
\hline H1 & Cost Benefit $=>$ Attitude & 0.295 & 2.165 & $* *$ & Supported \\
H2 & Knowledge=>Attitude & 0.009 & 0.052 & 0.958 & Not Supported \\
H3 & Religion=>Attitude & 0.164 & 1.178 & 0.239 & Not Supported \\
H4 & Business Support=>Attitude & -0.087 & 0.516 & 0.606 & Not Supported \\
H5 & Reputation=>Attitude & 0.470 & 3.524 & $* * *$ & Supported \\
H6 & Attitude $=>$ Using & 0.124 & 1.013 & 0.312 & Not Supported \\
H7 & Cost Benefit $=>$ Using & 0.142 & 2.258 & $* *$ & Supported \\
H8 & Halal Awareness $=>$ Using & 0.586 & 5.497 & $* * *$ & Supported \\
H9 & Using $=>$ Berkah & 0.159 & 2.339 & $* *$ & Supported \\
H10 & Berkah=>Intention & 0.516 & 3.663 & $* * *$ & Supported \\
H11 & Using $=>$ Intention & -0.028 & 0.221 & 0.825 & Not Supported \\
H12 & Halal Awareness $=>$ Intention & 0.198 & 1.661 & $*$ & upported \\
\hline
\end{tabular}


The results indicate that from the total twelve hypotheses, only seven hypotheses supported the hypotheses. First, the first hypothesis result shows that cost benefit toward the attitude of MSMEs into Islamic financing is statistically significant $(\mathrm{p}<0.05)$ and rejecting the null hypothesis. This study is consistent with the findings by Jaffar and Musa (2016) in that cost benefit is the important factor for MSMEs in Malaysia pertaining to their attitude to Islamic financing. Therefore, it suggests that Islamic financial institutions should consider their competitiveness by providing a great deal of benefits to the customer, especially in terms of cost of financing. Naturally, MSMEs in Yogyakarta, where the majority have low capital formation, are very sensitive with the cost of funds that they obtain from the financial institutions. Therefore, cost benefit is a significant variable for MSMEs to decide whether they will use Islamic financing.

Another variable that affects the attitude of MSMEs toward Islamic financing is Reputation. Reputation is statistically significant $(p<0.01)$ with in which $t$-value is 3.524. MSMEs This finding regarding the reputation is consistent with previous study, Kasuma et al. (2016) that stated, reputation is the key component in Islamic financing. This finding indicates that Halal MSMEs need to improve their reputation as halal companies. In accessing Islamic financing product, MSMEs will consider reputational aspects for their businesses. With good reputations, MSMEs will gain loyalty from their customers, and improve their business performance. Therefore, it is important for the policy makers to provide benefit for Islamic financing-based MSMEs via providing annual reward, publishing in mass media, and others.

As shown in the table above, Religion, Knowledge and Business support, are statistically not significant $(p>0.1)$ and accepting the null hypothesis. As far as religion is concerned, such findings contradict the study from Gait et al., (2009) which highlighted religion as the important aspect toward attitude. However, this finding is consistent with the previous study conducted by Haron, Ahmad, and Planisek (1994) and Dusuki (2008), both concluding that there were other factors that the customer normally took into account in making decision rather than merely a religious factor. This study indicates that the religious awareness of MSMEs in Yogyakarta is not good (Asmy, 2015).

In addition, for the variable of Knowledge of customer to Islamic financing product and Business support does not have any impact on the attitude of MSMEs in Yogyakarta toward Islamic financing. Therefore, the result of this study contradicts the study conducted by Ahmad and Haron (2002), Jaffar and Musa (2014), and Gait et al. (2009), all arguing that knowledge and business support were two significant aspects to attract the attitude of customer toward Islamic financing.

Interestingly, for the use of MSMEs into Islamic financing, attitude (perception) of MSMEs toward Islamic financing does not affect to the use of Islamic financing. It indicated by table above in which attitude is not statistically significant (t-value $=1.013, \mathrm{p}>0.1)$. This study is not consistent with the previous studies such as Lada et.al (2009), Razak and Abduh (2012), and Amin et.al (2009) that found the attitude played an important role in intention.

Furthermore, this study reveals that halal awareness and cost benefit are the key variables that determine the use of MSMEs to Islamic financing product. As far as Halal awareness among MSMEs in Yogyakarta is concerned, this research in 
fact argues that the knowledge of MSMEs in halal aspect have direct impact on the impression to use Islamic financing. This finding may confirm the previous study conducted by Ling et al. (2012) that stated that most of the respondents in Islamic banking were aware of the Islamic banking process and the details of product for financing activities. Hence, it suggests that for Islamic financial institutions, Islamic banks and policy makers should increase the marketing on the details of Islamic financing product that can be accessed by MSMEs, in particular showing halal aspects or halal elements in business activities, such as by campaigning halal logo for MSMEs.

Berkah as the key component and the major concept of Islamic economic is discussed in this paper. The basic question of this concern is whether using Islamic financing provides Berkah. Such a question is crucial since all references in major Islamic economic conceptualize this element. In Table 3, this study reveals that Berkah will be accepted by the customer due to the implementation of Islamic financing product. The table indicates that the null hypothesis is rejected $(p<0.05)$, with the coefficient 0.159 . It means that when the use of Islamic financing increases 1 point, the Berkah that is collected by the customer will increase by 0.159 point.

Moreover, such a finding provides an empirical evidence that by using Islamic financing, the customer will benefit Maslahah. In this regard, Maslahah consists of Manfaat and Berkah, in which Berkah will increase significantly by using halal product (P3EI and BI, 2012), or Berkah follows an exponential growth. By this finding, MSMEs should improve their use of Islamic financing. Consequently, they will get more Berkah in their life. Moreover, based on the information in the table, Berkah accepted by the MSMEs in Yogyakarta has positive impact on the intention of MSMEs for re-using Islamic financing. It is verified by the SEM result, where p-value of Berkah to Intention is below 0.05. Therefore, it is evident that Berkah provides good intentions with Islamic financing.

In addition, this study provides empirical evidence for the determinant of the intention to re-use Islamic financing, as the table shows that the Halal Awareness is statistically significant ( $\mathrm{p}$-value $<0.1$ ). This study supports the study from Rammal \& Zurbruegg (2007) that found the awareness of Australian Muslim on Islamic banking motivated their interest to use Islamic banking products. This indicates that the MSMEs understanding on the Halal certification encapsulated halal product (halal li-dzatihi) and another element of halal, which is halal in process (halal li-ghoirihi). Therefore, it is important to increase the halal understanding from the MSMEs in Yogyakarta.

\section{CONCLUSION AND RECOMMENDATIONS}

The findings of the study offer an important contribution to the industry practitioners and regulators in developing pertinent strategy to develop halal industry by incorporating Islamic financing. First, the attitude or perception of MSMEs into the Islamic financing could be improved by two components: cost benefit and reputation. Islamic financial institutions should be able to leverage their competitiveness with their conventional counterparts by attracting Halal MSMEs to using Islamic financing. In addition, religious campaigns could be improved by the regulators and Islamic financing practitioners via mass media or 
preaching in mosques, schools, and other places to improve more comprehensive understanding of MSMEs in relation to the halal aspect and Islamic financing. Finally, a reward system that will increase the reputation of MSMEs should also be considered to revitalize the attitude of MSMEs toward Islamic financing.

Second, as far as the use of Islamic financing instrument is concerned, cost benefit and halal awareness are the most important variables. It means that, for MSMEs, cost of fund is crucial in determining their decision in choosing financing instrument. In addition, government should be concerned of improving the halal awareness of MSMEs in order to increase the using of MSMEs for Islamic financing. Third, Berkah as the key component in Islamic financing is accepted by MSMEs when they implement Islamic financing instruments. Hence, it needs to be done by all Islamic financing's stakeholders to improve the understanding of MSMEs that Halal takes into account not only in the aspect of its product per se, but also the whole aspect of business and production, from the beginning to the end, including Islamic financing. Last, this study reveals that using Islamic financing instruments will motivate the intention of MSMEs to re-use Islamic financing. In addition, Berkah, which is accepted by MSMEs, will also encourage them to keep using the Islamic financing instrument. As a result, improving service to maintain the customer satisfaction and also preaching Berkah as the key component in Muslim life are the two important agenda in the future development of Halal Industry, especially in MSMEs sectors.

The paper recommends the market players to improve the competitiveness of Islamic financing product. This will attract more MSMEs to access Islamic financing instruments that comply with Shariah. Accessing Islamic financing for MSMEs is not only related to the business per se, but also the religious concerns to make sure that all business activities are in line with Islamic values. In addition, the paper also suggests for regulators on the significance of Halal and Berkah campaign for MSMEs to increase the halal awareness of MSMEs especially within Muslim society. Lastly, this paper argues that preaching agenda concerning Berkah campaign is critical to be undertaken since it will provide many benefits for the development of Islamic financing and Halal MSMEs in the long-term.

However, there are a few limitations of this study. Other variables might affect the use of MSMEs for Islamic financing. Consequently, there is a need to further examine other factors that may influence the use of Islamic financing. In addition, due to time constraint, the number of sample size could have been augmented as only 58 respondents were involved in this study.

Therefore, future research is still required that covers other factors influencing using of Islamic financing. In so doing, it will provide more comprehensive results in that more meaningful policies will be made and further implemented. Apart from that, the sample size of future study should be increased. Thus, SEM-AMOS could be employed. In addition, more sophisticated analysis could also be used such as Analytic Network Process (ANP) and Analytic Hierarchy Process (AHP) that would improve the research quality. 


\section{REFERENCES}

Ahmad, N., \& Haron, S. (2002). Perceptions of Malaysian Corporate Customers towards Islamic Banking Products and Services. International Journal of Islamic Financial Services, 3(4).

Amin, H., Rahman, A. R. A., Jr, S. L. S., \& Hwa, A. M. C. (2011). Determinants of Customers' Intention to Use Islamic Personal Financing. The Case of Malaysian Islamic Banks. Journal of Islamic Accounting and Business Research, 2(1), 22-42. https://doi.org/10.1108/17590811111129490

Amin, H., Hamid, M. Lada, S. and Anis, Z. (2008), “The Adoption of Mobile Banking in Malaysia The Case of Bank Islam Malaysia Berhad (BIMB)", International Journal of Business and Society, Vol. 9 No. 2, pp. 43-53.

Ardhy, H. S. S. (2015). Measuring the Customer Satisfaction of Islamic Banking Sector. Ecoforum, 4(1), 290-299.

Ascarya, \& Rahmawati, S. (2018). Analysis of the Determinants of Micro Enterprises Graduation. Jurnal of Islamic Economics, Banking and Finance, 14(2), 12-60.

Asmy, M. (2015), A Proposed Integrated Cash Waqf Micro Enterprise Investment (ICWME-I) Model For Mitigating The Financial and Human Capital Development Challenges of Micro Enterprises In Malaysia. Unpublished manuscript.

Bahruddin, K., Kassim, N. A., Nordin, S. K., \& Buyong, S. Z. (2015). Understanding the Halal Concept and the Importance of Information on Halal Food Business Needed by Potential Malaysian Entrepreneurs. International Journal of Academic Research in Business and Social Sciences, 5(2), 170-180. https://doi.org/10.6007/ IJARBSS/v5-i2/1476

Balushi, Y. Al, Locke, S., \& Boulanouar, Z. (2018). Islamic Financial DecisionMaking among SMEs in the Sultanate of Oman: An Adaption of the theory of Planned Behavior. Journal of Behavioral and Experimental Finance. https://doi. org/10.1016/j.jbef.2018.06.001

Bodibe, S., Chiliya, N., \& Tarisayi, C. (2016). The Factors Affecting Customers' Decisions to Adopt Islamic Banking. Banks and Bank Systems, 11(4), 144151.

Boocock, J. G., \& Preseley, J. R. (1993). Equity Capital for Small and MediumSized Enterprises in Malaysia : Venture Capital or Islamic Finance. Managerial Finance, 19(7), 82-95.

Dusuki, A. W. (2008). Understanding the Objectives of Islamic Banking: a Survey of Stakeholders' Perspectives. International Journal of Islamic and Middle Eastern Finance and Management, 1(2), 132-148. https://doi. org/10.1108/17538390810880982

Dusuki, A. W., (2008). Banking for the Poor: The Role of Islamic Banking in Microfinance Initiatives. Humanomics, Vol.24 (1), pp. 9-66.

Demiler, S., \& Sahib, H. B. (2015). Concept of Barakah in Qur' ān and Sunnah : Towards its Realization in Modern Discourse. Jounal of Humanities and Social Sciences, (5).

F. Hair Jr, J., Sarstedt, M., Hopkins, L., \& G. Kuppelwieser, V. (2014). Partial least squares structural equation modeling (PLS-SEM): An emerging tool in business research. European Business Review, 26(2), 106-121. https://doi.org/10.1108/ EBR-10-2013-0128. 
Farid, M. (2013). Analisis Tingkat Kepuasan Nasabah Non Muslim terhadap Kualitas Pelayanan pada Bank Syariah di Kota Medan Miftah Farid. Jurnal Ekonomi Dan Keuangan, 1(13).

Fianto, B. A., Gan, C., Hu, B., \& Roudaki, J. (2017). Pacific-Basin Finance Journal Equity Financing and Debt-Based Financing: Evidence from Islamic Micro Finance Institutions in Indonesia. Pasific-Basin Finance Journal, (August 2016). https://doi.org/10.1016/j.pacfin.2017.09.010

Gait, A. H., Worthington, A., Gait, A. H., \& Worthington, A. C. (2009). Libyan Business Firm Attitudes towards Islamic Methods in Finance Libyan Business Firm Attitudes towards Islamic Methods of Finance. Griffith Business School. Discussion Paper Finance.

Ghazali, Imam. (2015). Partial Least Squares; Konsep, Tekhnik dan Aplikasi Menggunakan Program Smart PLS 3.0. Semarang: Badan Penerbit Undip.

Hanif, M., \& Iqbal, A. M. (2010). Kent Academic Repository. European Journal of Social Sciences, 15(4), 475-489.

Haron, S.,Ahmad, N. and Planisek, L. (1994), “Bank Patronage Factors of Muslim and non-Muslim Customers", International Journal of Bank Marketing, Vol. 12 No.1, pp. 32-40.

Huda, A. N. (2012). The Development of Islamic Financing Scheme for SMEs in a Developing Country: The Indonesian Case. Procedia - Social and Behavioral Sciences, 52, 179-186. https://doi.org/10.1016/j.sbspro.2012.09.454

Hussaini, S. M., \& Malami, H. U. (2014). Test of Acceptability of Profit and Loss Sharing Financing Arrangements by Small Scale business in and around Kano city in Northen Nigeria. European Scientific Journal, 8(1), 293-309.

Jaffar, M. A., \& Musa, R. (2014). Determinants of Attitude towards Islamic Financing among Halal- Certified Micro and SMEs: A Preliminary Investigation. Procedia - Social and Behavioral Sciences, 130, 135-144. https://doi.org/10.1016/j. sbspro.2014.04.017

Jaffar, M. A., \& Musa, R. (2016). Determinants of Attitude and Intention towards Islamic Financing Adoption among Non-Users. Procedia Economics and Finance, 37(16), 227-233. https://doi.org/10.1016/S2212-5671(16)30118-6

Kassim, S. (2016). Islamic Finance and Economic Growth:The Malaysian Experience. Global Finance Journal, 30, 66-76. https://doi.org/10.1016/j.gfj.2015.11.007

Kasuma, J., Su, T., Kanyan, A., Kamri, T., \& Yacob, Y. (2016). Determinants of Micro Enterprise Owners ' Loyalty towards Their Favourite Banks. Procedia - Social and Behavioral Sciences, 224(August 2015), 301-307. https://doi.org/10.1016/j. sbspro.2016.05.489

Lada, S.,Tanakinjal, G.H. and Amin, H. (2009), "Predicting Intention to Choose Halal Products using Theory of Reasoned Action", International Journal of Islamic and Middle Eastern Finance and Management, Vol. 2 No. 1, pp. 66-76.

Ling, K. L., Ling, K. M., Pey, L. S., \& Hui, W. Z. (2012). Awareness of Islamic Banking Products and Services among Non-Muslims in Malaysia.

Lone, F. A., Aldawood, E. M., \& Bhat, U. R. (2017). Comparative Analysis of Customer Satisfaction towards Islamic and Conventional Banking: An Empirical Study from Saudi Arabia. International Review of Management and Marketing, 7(1), 273-280. 
Metawa, A. S. and Al-Mossawi, M. (1998), "Banking Behavior of Islamic Bank Customers: Perspectives and Implications", International Journal of Bank Marketing, Vol. 16 No. 7,pp. 299-313.

Minhat, M., \& Dzolkarnaini, N. (2017). Which Firms use Islamic financing? Economics Letters, 150, 15-17. https://doi.org/10.1016/j.econlet.2016.10.036

Mukhtar, A., Butt, M. M., Mukhtar, A., \& Butt, M. M. (2012). Religiosity Intention to choose Halal products : The Role of Religiosity. Journal of Islamic Marketing, 3(2), 108-120. https://doi.org/10.1108/17590831211232519

Nawafleh, S., Al-Ajlouni, M. I., Al-Tamimi, J. A., \& Shiab, A. Q. (2018). Factors Affecting Client's Intentions of Use Islamic Financing: Filed Study in the Jordanian Context. In Innovation Management and Education Excellence through Vision 2020.

Norvadewi. (2015). Bisnis Dalam Perspektif Islam. Al-Tijary, 1(1), 33-46.

Rahman, A. R. A. (2010). Islamic microfinance: An Ethical Alternative to Poverty Alleviation. Humanomics, 26(4), 284-295. https://doi. org/10.1108/08288661011090884

Rammal, H. G., \& Zurbruegg, R. (2007). Awareness of Islamic Banking Products among Muslims : The Case of Australia. Journal of Financial Services Marketing, 12, 65-74. https://doi.org/10.1057/palgrave.fsm.4760060

Rasheed, R., Siddiqui, S. H., \& Rahman, M. A. (2018). Influence of Awareness on SME' s Intention towards Adoption of Islamic Finance in Pakistan. Review of Economics and Development Studies, 4(1), 51-59. https://doi.org/10.26710/reads. v4i1.224

Razak, D. A. and Abduh, M. (2012), "Customers Attitude towards Diminishing Partnership Home Financing in Islamic Banking", American Journal of Applied Sciences, Vol. 9 No. 4, pp. 593-599.

Richter, N. F., Sinkovics, R. R., Ringle, C. M., \& Schlägel, C. (2016). A Critical Look at the use of SEM in International Business Research. International Marketing Review, 33(3), 376-404. https://doi.org/10.1108/IMR-04-2014-0148

Rustam, S., Bibi, S., Zaman, K., Rustam, A., \& Zahid-ul-Haq. (2011). Perceptions of Corporate Customers Towards Islamic Banking Products and Services in Pakistan. The Romanian Economic Journal, 15(41), 107-123.

Sakti, M. R. P., Thaker, H. bin M. T., Qayum, A., \& Qizam, I. (2016). Determinant of Cash Waqf Contribution in Klang Valley and Selangor: A SEM Approach. Journal of Islamic Monetary Economics and Finance, 2(1), 111-144.

Shaban, M., Duygun, M., \& Fry, J. (2016). SME's Lending and Islamic Finance. Is it a "win - win" Situation ? Economic Modelling, 55, 1-5. https://doi.org/10.1016/j. econmod.2016.01.029

Thomson Reuters. (2017). State of the Global Islamic Economy Report 2016-2017.

Wulandari, D., \& Subagio, A. (2015). Consumer Decision Making in Conventional Banks and Islamic Bank based on Quality of Service Perception. Procedia - Social and Behavioral Sciences, 211(September), 471-475. https://doi.org/10.1016/j. sbspro.2015.11.062

Yunos, R. M., Mahmood, C. F. C., \& Mansor, N. H. A. (2014). Understanding Mechanisms to Promote Halal Industry-The Stakeholders' Views. Procedia - Social and Behavioral Sciences, 130, 160-166. https://doi.org/10.1016/j. sbspro.2014.04.020 
Zainuddin, Z., Hamja, Y., \& Rustiana, S. H. (2016). Analisis Faktor Dalam Pengambilan Keputusan Nasabah memilih Produk Pembiayaan Perbankan Syariah (Studi Kasus pada PT. Bank Syariah Mandiri Cabang Ciputat). Jurnal Keuangan Dan Perbankan, 13(December 2016), 55-76. 